\title{
WITAMINY I MIKROELEMENTY W CHEMOPREWENCJI RAKA BŁONY ŚLUZOWEJ TRZONU MACICY ORAZ RAKA JAJNIKA
}

\section{VITAMINS AND MICROELEMENTS IN THE CHEMOPPREVENTION OF ENDOMETRIAL CANCER AND OVARIAN CANCER}

\author{
Katarzyna Plagens-Rotman \\ Państwowa Wyższa Szkoła Zawodowa im. Hipolita Cegielskiego w Gnieźnie
}

https://orcid.org/0000-0001-7646-7430

DOI: https://doi.org/10.20883/pielpol.2021.3

\begin{abstract}
STRESZCZENIE
Chemoprewencja czyli zapobieganie nowotworom złośliwym poprzez wykorzystanie naturalnych lub syntetycznych związków chemicznych, może stanowić cenne narzędzie w walce z nowotworami, które stanowią jeden z najważniejszych problemów zdrowia publicznego. Ochronny mechanizm działania witaminy C, E, selenu oraz karotenoidów polega przede wszystkim na hamowaniu oksydacyjnych uszkodzeń tkanek lub DNA poprzez zmiatanie wolnych rodników tlenowych, regulację proliferacji oraz apoptozę komórek atypowych. Witamina D przyczynia się do hamowania nadmiernej proliferacji oraz stymuluje różnicowanie się komórek, a poprzez zwiększenie różnicowania tkanek i propagowanie apoptozy obniża ryzyko powstawania przerzutów. Redukuje ryzyko rozwoju raka jajnika, gruczołu piersiowego, macicy, a także pęcherza moczowego, przełyku oraz okrężnicy.
\end{abstract}

SŁOWA KLUCZOWE: witaminy, antyoksydanty, mikroelementy, profilaktyka, nowotwory złośliwe.

\section{Wstęp}

Witaminy i mikroelementy stanową liczną grupę składników odżywczych, których niedobór lub ich brak może prowadzić do zmian morfologicznych lub fizjologicznych pogarszających zdolność funkcjonowania organizmu, zmniejszających odporność na stres czy zwiększających wrażliwość na szkodliwe działanie czynników środowiskowych. Witaminy pełnią rolę regulacyjną - jako biokatalizatory utrzymują prawidłową czynność komórek. Ponadto poprzez system enzymatyczny uczestniczą w regulacji wielu procesów biochemicznych.

Chemoprewencja jest metodą zapobiegania powstawaniu nowotworów złośliwych poprzez stosowanie naturalnych lub syntetycznych związków chemicznych ale także przyjmowanie ich wraz z pożywieniem w postaci odpowiednio dobranej diety, czego efektem może być zatrzymanie lub wyhamowanie przebiegu karcenogenezy.

\begin{abstract}
Chemoprevention, or prevention of malignant tumours by using natural or synthetic chemical compounds, can be an invaluable tool in the fight against cancer - one of the most substantial public health problems. A defence mechanism of vitamin C, E, selenium and carotenoids is based on the inhibition of oxidative damages of tissues or DNA by sweeping free oxygen radicals, regulating proliferation and apoptosis of atopic cells. Vitamin D inhibits excessive proliferation and stimulates cell differentiation, and by increasing the differentiation of tissues and promoting apoptosis, it reduces the risk of metastasis. Furthermore, vitamin $D$ decreases the risk of ovarian cancer, breast cancer, uterine carcinoma, bladder cancer, oesophagal and colon carcinoma development.
\end{abstract}

KEYWORDS: vitamins, antioxidants, micronutrients, prophylaxis, malignant neoplasms.

\section{Strategie chemoprewencyjne}

Chemoprewencja pierwotna oznacza stosowanie środków hamujących rozwój nowotworu na etapie inicjacji. Obejmuje osoby zdrowe z grupy podwyższonego ryzyka, narażone na działanie czynników kancerogennych, z predyspozycją do rozwoju nowotworu występującego rodzinnie.

Chemoprewencja drugiego rzędu polega na hamowaniu progresji nowotworu oraz stosowaniu terapii zdiagnozowanych wcześniej stanów przedrakowych.

Chemoprewencja trzeciego rzędu - polega na zapobieganiu nawrotom choroby i stanowi środek prewencyjny przeciw drugiemu nowotworowi pierwotnemu [1].

\section{Czynniki chemoprewencyjne}

Wśród czynników chemoprewencyjnych wyróżnia się czynniki blokujące i supresyjne. Czynniki blokujące mają za zadanie hamowanie aktywacji metabolicznej kancerogenu, unieczynnienie reaktywnych metabolitów 
oraz wolnych rodników, zapobiegając tym samym ich reakcji z DNA, zwiększając skuteczność systemów naprawczych DNA oraz indukowanie apoptozy.

Czynniki supresyjne - przyczyniają się do hamowania procesu kancerogenezy poprzez zmiatanie reaktywnych form tlenu (ROS, ang. reactive oxygen species), modulowanie dróg transdukcji sygnału, hamowanie procesów zapalnych oraz proliferacji. Ponadto inicjują proces apoptozy [1, 2].

Wolne rodniki tlenowe odgrywają istotną rolę $\mathrm{w}$ patogenezie chorób, w tym także nowotworów złośliwych. Wolne rodniki to cząsteczki zbudowane z co najmniej jednego atomu tlenu i jednego lub więcej niesparowanych elektronów na orbitalu walencyjnym. Powstają w wyniku wielu procesów metabolicznych, uczestnicząc m.in. w funkcjonowaniu układu obronnego, wydzielaniu hormonów czy regulacji napięcia naczyniowego. Czynnikami egzogennymi przyspieszającymi powstawanie w nadmiarze ROS może być palenie tytoniu, spożywanie alkoholu, zanieczyszczenie powietrza, infekcje, stres oraz intensywny wysiłek fizyczny. Dodatkowe źródła mogą stanowić promieniowanie jonizujące czy zanieczyszczenie środowiska. Wzrost wytwarzania wolnych rodników, zmniejszenie aktywności systemów enzymatycznych przyczyniających się do ich usuwania oraz spadek aktywności antyoksydacyjnej prowadzi do niewystarczającego usuwania ich przez mechanizmy obronne organizmu. Powstające zmiany w obrębie komórek i tkanek są przyczyną przyspieszenia procesu starzenia się organizmu, chorób degeneracyjnych oraz procesu karcynogenezy [3, 4].

Działanie wolnych rodników tlenowych równoważone jest poprzez antyoksydanty hamujące stopień oksydacji cząsteczek. Ponadto powodują przekształcanie się tych rodników w nieaktywne pochodne. Antyoksydacyjny układ ochronny (ADS; ang. antioxidant defense system) przyczynia się do udaremnienia inicjacji reakcji utleniania oraz naprawy obecnych uszkodzeń. Powstałe wolne rodniki przekształcane są w $\mathrm{O} 2$ lub $\mathrm{H} 2 \mathrm{O}$ [3].

\section{Mechanizmy usuwania wolnych rodników tlenowych}

Wśród mechanizmów usuwania wolnych rodników podkreśla się rolę systemu nieenzymatycznego i enzymatycznego.

System nieenzymatyczny, czyli substancje ochronne (tzw. zmiatacze wolnych rodników), przekazują swoje elektrony wolnym rodnikom tlenowym, przechodząc w postać utlenioną. Ponadto zabezpieczają komórki przed reakcjami wolnorodnikowymi. Należą do nich: witamina $A$, witamina $E$, witamina $C, \beta$-karoten.

System enzymatyczny - wyspecjalizowane enzymy przeprowadzające reakcje usuwania wolnych rodników oraz zapobiegające ich powstaniu. Do tego systemu zalicza się: dysmutazę ponadtlenkową (SOD, ang. superoxi- de dismutase), katalaze (CAT, ang. catalase), peroksydazę glutationową (Gpx, ang. glutathione peroxidase), zredukowaną formę glutationu (GSH, ang. reduced glutathione), dehydrogenazę glukozo-6-fosforanową [3, 4].

\section{Witamina A (retinol)}

Witamina A oraz jej syntetyczne analogi (retinoidy) należą do witamin rozpuszczalnych w tłuszczach uczestniczących w procesie syntezy hormonów steroidowych, podziałów komórkowych oraz wzmacniania układu odpornościowego oraz zapobiegania zakażeniom. Ponadto uczestniczy w modulowaniu transkrypcji genów przy współudziale receptorów RAR (ang. retinoic acid receptors) oraz $R X R$ (ang. retinoid $X$ receptors) należących do czynników transkrypcyjnych regulowanych przez wiązanie ligandu. Receptory RAR oraz RXR mogą wpływać na hamowanie rozwoju niektórych nowotworów złośliwych poprzez obniżenie ekspresji lub aktywności tych receptorów $[1,5,6]$.

$\mathrm{U}$ kobiet uczestniczących w projekcie The Pooling Project of Prospective Studies of Diet and Cancer (Pooling Project) prowadzonym przez Koushik i wsp. [7] wykryto 1973 przypadki raka jajnika wśród 501878 tysięcy badanych kobiet pomiędzy 27. a 93. rokiem życia. Nie stwierdzono jednak różnicy w grupach przyjmujących i nieprzyjmujących witaminę $A$ na rozwój raka między przyjmowaniem witaminy $A$ w rozwoju raka jajnika $(\mathrm{OR}=1,01 ; 95 \% \mathrm{Cl} 0,99-1.04)$. Potwierdzają to również badania Thomson i wsp. [8], w których to przyjmowanie witaminy A nie wpływało istotnie na zmniejszenie ryzyka zachorowania na raka jajnika (OR $=1.05$; 95\% Cl $0.80-1.38)$.

Fenretinoid [N-4-hydroxyphenyl retinamide (4 - HPR)] jako jedyna pochodna witaminy A charakteryzująca się wąskim profilem działań niepożądanych znajduje zastosowanie w hamowaniu raka błony śluzowej trzonu macicy. Mechanizm działania fenretinoidu nie jest do końca poznany, jednak przypuszcza się, że stanowi on selektywny modulator receptora retinowego oraz indukuje apoptozę komórek guza. Ponadto zmniejsza stężenie insulinopodobnego czynnika wzrostu IGF - 1 (ang. Insulin - like Growth Factor 1) [9]. W badaniach Tanabe i wsp. [10] podawanie syntetycznego analogu kwasu retinowego (AM580), po upływie 96 godzin, powodowało znaczne zahamowanie wzrostu komórek raka błony śluzowej trzonu macicy w hodowli i wzrostu ekspresji supresorowego RAR - $\beta$ w stosunku do grupy kontrolnej.

\section{Witamina E}

Witamina E należy do witamin rozpuszczalnych w tłuszczach, występuje w postaci 8 izomerów: 4 tokoferole $(\alpha-$, $\beta-, \gamma-, \delta-)$ oraz 4 tokotrienole $(\alpha-, \beta-, \gamma-, \delta-)$ [11-12]. 
Właściwości antyoksydacyjne tokoferoli są dobrze poznane, szczególnie ich zdolności do ochrony przed utlenianiem wielonienasyconych kwasów tłuszczowych oraz do przerywania łańcuchowej peroksydacji lipidów. Uczestniczy w syntezie substancji przeciwkrzepliwych, dostarczaniu składników odżywczych do komórek, ochronie krwinek czerwonych czy ekspresji genów. Wspomaga prawidłowe funkcjonowanie wzroku, prawidłową wydolność mięśni i wytwarzanie nasienia u mężczyzn. Ponadto witamina E wykazuje działanie ochronne przed mutagennym działaniem RFT (ang. reactive oxygen species; reaktywne formy tlenu) $[13,14]$. Hamuje aktywność kinazy białkowej C (PKC), cyklooksygenazy-2 (COX-2) oraz fosfolipazy A2 [15]. Badania Zing i wsp. [16] wykazały, że inhibicja aktywności PKC indukowana przez a-tokoferol przyczynia się do zahamowania wzrostu komórek mięśni gładkich oraz obniżenia proliferacji komórkowej rożnych nowotworów [17, 18].

Thomson i wsp. [19] w badaniu Women's Health Initiative (WHI) poddali analizie 133614 kobiet w wieku pomenopauzalnym. Cytowani autorzy nie dowiedli wpływu przyjmowania witaminy $\mathrm{E}$ na zmniejszenie ryzyka zachorowania na raka jajnika $(\mathrm{OR}=1,05$; $95 \% \mathrm{Cl}$ 0,71 - 1,57). Potwierdzają to również badania Gifkins i wsp. [20] oraz Chang i wsp. [21].

$\mathrm{W}$ badaniach prowadzonych przez Xu i wsp. [22] w grupie 1212 kobiet zdiagnozowano 1204 nowych rozpoznań raka błony śluzowej trzonu macicy. Zwrócono uwagę na związek spożywania witaminy $\mathrm{E}$ z obniżeniem ryzyka raka endometrium ( $\mathrm{OR}=0,82 ; 95 \% \mathrm{Cl}$ 0,72-0,93). W pracy McCann i wsp. [23] ryzyko to kształtowało się na poziomie OR = 0,52; 95\% Cl 0,22 - 1,27, w pracy Negri i wsp. [24] OR $=0,87 ; 95 \%$ Cl 0,57 - 1,51. W pracy Gifkins i wsp. [20] nie wykazano takiego związku.

\section{Witamina C}

Witamina C (kwas askorbinowy; AA) należy do witamin rozpuszczalnych w wodzie. Została wyizolowana przez Kinga w 1932 roku z soku z cytryny; zidentyfikowana jako identyczna z kwasem heksuronowym, wyodrębnionym w 1928 roku przez Szent-Györgyiego [24].

Spożywanie kwasu askorbinowego związane jest z działaniem ochronnym w nowotworach płuc, jelit, trzustki, pęcherza moczowego, odbytu oraz w chorobach sercowo-naczyniowych. Ponadto przyczynia się do zmniejszenia ryzyka zachorowania na nowotwory gruczołu piersiowego oraz błony śluzowej trzonu macicy u kobiet, które spożywały znaczne ilości tej witaminy [25-27].

Udowodniono, że kwas askorbinowy w połączeniu m.in. z witaminą E u osób palących papierosy hamuje podwyższone markery peroksydacji lipidów. Poprzez zdolności antyoksydacyjne kwas askorbinowy przyczy- nia się do ochrony komórek organizmu przed stresem oksydacyjnym [27]. Zażywana doustnie wykazuje działanie kardioprotekcyjne, ograniczając peroksydację lipidów [28]. Pełni funkcję ochronną przed tworzeniem się mutagennych $\mathrm{N}$ - nitrozozwiązków poprzez blokowanie reakcji nitrozowania. Zwiększa aktywność komórek NK (ang. natural killer) oraz limfocytów B i T [29]. Ponadto reguluje ciśnienie tętnicze krwi, obniża stężenie glukozy we krwi w stanach hiperglikemii oraz bierze udział w odbudowie tkanek podczas gojenia się [30].

Badania epidemiologiczne wskazują, że podawanie kwasu askorbinowego związane jest $z$ tworzeniem rodników askorbinionowych wytwarzających nadtlenek wodoru (H2O2) w płynie pozakomórkowym w stężeniu, który jest cytotoksyczny dla wielu komórek nowotworowych [31]. W badaniach Drisko i wsp. [31] kobietom z rozpoznanym rakiem jajnika w III stopniu zaawansowania klinicznego, leczonym cytostatykami (karboplatyna i paklitaksel, KT), podawano drogą dożylną witaminę C w ilości do $60 \mathrm{~g}$ dwa razy w tygodniu, a następnie raz w tygodniu po zakończeniu leczenia. Po okresie 40 miesięcy nie wykazano progresji choroby.

W pracy Kuiper i wsp. [33] badano związek pomiędzy zawartością askorbinianu, aktywacją szlaku HIF-1 (ang. hypoxia - inducible factor 1; czynnik indukowany hipoksją 1) a nowotworami złośliwymi błony śluzowej trzonu macicy. Stwierdzono odwrotną korelację pomiędzy askorbinianem a poziomem białka VEGF (ang. vascular endothelial growth factor; Czynnik wzrostu śródbłonka naczyniowego, VEGF). Wzrost poziomu innych markerów aktywacji HIF-1 (białka HIF-1 $\alpha$, GLUT-1 i BNIP3) był związany z niskim poziomem stężenia kwasu askorbinowego.

\section{Witamina D}

Badania epidemiologiczne wskazują, że ryzyko zachorowania na nowotwory złośliwe gruczołu piersiowego, jajnika, prostaty oraz jelita grubego jest odwrotnie proporcjonalne do szerokości geograficznej oraz stężenia witaminy D w surowicy krwi. Zwiększona ekspozycja na światło słoneczne osoby o jasnej karnacji koreluje ze zmniejszoną śmiertelnością w powyższych nowotworach. Podobne wyniki uzyskali Grant i Garland [34]. Prawdopodobnie osoby zapadające na nowotwory złośliwe gruczołu piersiowego, prostaty oraz jelita grubego, w okresie letnio-jesiennym, wykazują dłuższą przeżywalność w stosunku do osób chorujących w okresie zimowo-wiosennym [35].

Wielokierunkowe działanie witaminy $D$ polega na regulacji gospodarki wapniowo-fosforanowej, utrzymaniu homeostazy obejmującej wiele tkanek, hamowaniu proliferacji komórkowej, stymulacji różnicowania się komórek czy ochronie przed mutacjami, leżącymi u podstaw transformacji nowotworowej i progresji nowotworu [36, 37]. 
1,25(OH)2D3 (Calcitriolum; 1,25 - dihydroksycholekalcyferol) hamuje proliferację i stymuluje różnicowanie w komórkach linii białaczkowych M1 i HL-60, jelita grubego, gruczołu piersiowego, prostaty oraz płuc, w których stwierdzono ekspresję genu VDR [38-40]. Przejście komórek z fazy G1 do S cyklu komórkowego odbywa się za pośrednictwem fosforylacji białka retinoblastoma (Rb), katalizowanego przez cykliny G1 i zależne od nich kinazy (CDK, ang. cyklin dependent kinase). 1,25(OH)2D3 hamuje sygnały mitogenne przekazywane przez czynniki wzrostu, w tym między innymi EGF (ang. epithelial growth factor; receptor dla nabłonkowego czynnika wzrostu), pobudza szlaki transformujące TGF-b (ang. transforming growth factor b) i białka wiążące IGF - BP (ang. insulin - like growth factor binding protein; insulinopodobny czynnik wzrostu). Witamina D może hamować aktywność prostaglandyn, ekspresję protoonkogenu $\mathrm{bcl}-2$ oraz hamować aktywację transkrypcji genu IL-8 [41, 42].

W badaniu National Health and Nutrition Examination Surveys Bakhru i wsp. [43], oznaczając stężenie $25(\mathrm{OH}) \mathrm{D}$, zaobserwowali ponad trzykrotnie niższe stężenie witaminy $D$ w grupie kobiet $z$ rozpoznanym rakiem jajnika niż w grupie kontrolnej. Potwierdzają to również badania Lu Yin i wsp. [44], którzy w metaanalizie wykazali istnienie słabego związku pomiędzy stężeniem witaminy $D$ a ryzykiem zachorowania na raka jajnika.

W badaniach Walentowicz-Sadleckiej i wsp. [45] zaobserwowano niedobór 25(OH)D w populacji kobiet z rakiem jajnika. Średnie stężenie witaminy $D$ w surowicy krwi u pacjentek ze zdiagnozowanym rakiem jajnika oraz w grupie kontrolnej wynosiło odpowiednio 12,4 ng/ $\mathrm{ml}$ oraz 22,4 ng/ml. Ponadto zaobserwowano niższy odsetek 5-letnich przeżyć, co prawdopodobnie może świadczyć o agresywnym przebiegu choroby przy niskich stężeniach witaminy D w surowicy krwi.

Przypuszcza się, że witamina D wraz z progesteronem mogą wykazywać działanie protekcyjne w przypadku raka błony śluzowej trzonu macicy poprzez hamowanie VDR proliferacji komórek endometrium na drodze aktywacji kaspazy 3 czy stymulując wpływ progesteronu i witaminy D na białko Bax. Jednak w badaniu The Nurses' Health Study (NHS) [46] nie stwierdzono związku pomiędzy spożywaniem witaminy $D$ a częstością występowania raka błony śluzowej trzonu macicy.

\section{Kwas foliowy}

Rola kwasu foliowego (witamina B9, określana również jako B11) w profilaktyce nowotworów złośliwych nie do końca została poznana. Badania epidemiologiczne wskazują na odwrotną zależność pomiędzy spożywaniem folianów w diecie a ryzykiem zachorowania na raka jajnika, gruczołu piersiowego czy raka błony śluzowej trzonu macicy. Niedostateczna podaż kwasu foliowego jest przyczyną nieprawidłowego przebiegu procesów naprawczych i syntezy DNA, wzrostu częstości mutacji i niewłaściwej metylacji DNA. Badania na zwierzętach wykazały 10-krotnie wyższy poziom aberracji chromosomowych w komórkach jajnika wśród chomików chińskich pozbawionych kwasu foliowego [46-49].

Kwas foliowy $\mathrm{i}$ jego pochodne znajdują się w produktach pochodzenia roślinnego i zwierzęcego. Wśród produktów roślinnych wysoką zawartość obserwuje się w surowych i krótko gotowanych warzywach liściastych (brokuły, szpinak, brukselka, kapusta włoska, korzeń i liść pietruszki, sałata). W nasionach roślin strączkowych (groch, fasola, soja) zawartość folianów waha się od 150-200 $\mu \mathrm{g} / 100 \mathrm{~g}$. Bogatym źródłem folianów są również warzywa i owoce mające w swoim składzie witaminę $\mathrm{C}$ lub $\beta$-karoten (papryka, jarmuż, pietruszka, maliny, kiwi, pomarańcze), orzechy arachidowe mające $110 \mu \mathrm{g} / 100 \mathrm{~g}$ i orzechy włoskie mające od $66 \mu \mathrm{g} / 100 \mathrm{~g}$ foliantów. Wśród produktów pochodzenia zwierzęcego bogatym źródłem folianów są podroby, głównie wątroba $(200-580 \mu \mathrm{g} / 100 \mathrm{~g})$.

Larsson i wsp. [50] poddali analizie 61084 kobiet w przedziale wiekowym 38-76 lat. Cytowani autorzy dowiedli wpływ spożywania kwasu foliowego na obniżenie o 1/3 ryzyka zachorowania na raka jajnika u kobiet spożywających minimum 204 mikrogramów dziennie kwasu foliowego na dobę w stosunku do kobiet spożywających mniej niż 155 mikrogramów dziennie.

W innych badaniach, analizując 157 przypadków zdiagnozowanego raka jajnika przy łącznej liczbie 121700 kobiet, Kotsopoulos i wsp. [51] wykazali również ochronny wpływ spożywania kwasu foliowego w dawce $\geqslant 300$ $\mu \mathrm{g} /$ dobę. Ryzyko zachorowania dla tych kobiet kształtował się na poziomie OR =0,62; 95\% Cl 0,40-0,96.

Związek pomiędzy spożywaniem kwasu foliowego a ryzykiem zachorowania na raka błony śluzowej trzonu macicy jest nadal niejednoznaczny. W metaanalizie Du i wsp. [52], uwzględniając dziewięć badań kontrolnych i pięć badań kohortowych, wskazują na mniejsze ryzyko wystąpienia choroby u osób przyjmujących kwas foliowy OR = 0,89 95\% Cl: 0,76-1,05. Należy jednak podejmować kolejne działania zmierzające do oceny ryzyka zachorowania na raka jajnika czy błony śluzowej trzonu macicy.

\section{Selen}

Dowiedziono zależność pomiędzy niedostatecznym spożywaniem selenu a występowaniem schorzeń przewodu pokarmowego, stawów, nerwów, mózgu czy w chorobach cywilizacyjnych. Zaleca się spożywanie selenu w ilości $55 \mu \mathrm{g}$ na dobę. Spożywanie tego pierwiastka w ilości 100-200 $\mu \mathrm{g}$ dziennie przyczynia się do 
hamowania uszkodzeń materiału genetycznego i rozwoju procesu nowotworowego u ludzi [53].

Protekcyjne działanie selenu w profilaktyce nowotworów złośliwych polega na wzmacnianiu komórkowej odpowiedzi immunologicznej, działaniu przeciwzapalnym, hamowaniu peroksydacji lipidów i oksydacyjnego uszkadzania DNA. Selen wykazuje działanie antyproliferacyjne w stosunku do komórek nowotworowych, może indukować proces apoptozy komórek. Ponadto wykazuje wpływ na metabolizm kancerogenów poprzez hamowanie enzymów I fazy metabolizowania ksenobiotyków - aktywacji metabolicznej kancerogenów oraz aktywację enzymów II fazy [54, 55].

\section{Cynk}

Cynk to mikroelement odgrywający w organizmie człowieka wiele funkcji, w tym: jako niezbędny pierwiastek śladowy w syntezie białek, kwasów nukleinowych, uczestniczy w procesie mineralizacji kości oraz regeneracji tkanek. Ponadto uczestniczy w przemianach białek, tłuszczów i węglowodanów. Jony tego metalu biorą również udział w modyfikacji transkrypcji i naprawy DNA, hamowaniu apoptozy, aktywacji lub inhibicji enzymów, a także regulują komórkowe przekazywanie sygnałów.

Prawdopodobnie niskie spożycie cynku związane jest z występowaniem raka jajnika, prostaty, pęcherzyka żółciowego, płuc, głowy i szyi jako następstwo proliferacji komórek oraz promowania powstawania stanów zapalnych.

\section{Podsumowanie}

Istnieje wiele dowodów naukowych na to, iż w profilaktyce nowotworów złośliwych, m.in. w obrębie narządu rodnego u kobiet, istotną rolę odgrywają naturalne i syntetyczne związki chemiczne. Spożywanie witamin wykazujących właściwości przeciwnowotworowe poprzez racjonalny oraz systematyczny dobór posiłków może przyczynić się do zapewnienia organizmowi odpowiednich składników odżywczych, w tym witamin i mikroelementów.

\section{Piśmiennictwo}

1. Cyranka M, Kapka L, Rzeski W. Chemoprewencja nowotworów - perspektywy zastosowania w profilaktyce i terapii. Zdr Publ 2009; 2: 223-227.

2. Baer-Dubowska W, Bartoszek E, Malejka-Giganti D. Carcinogenic and anticarcinogenic food components. CRC Press Taylor\&Francis, Boca Raton New York 2005.

3. Czajka A. Wolne rodniki tlenowe a mechanizmy obronne organizmu. Nowiny Lekarskie 2006; 6: 582-586.

4. Roszkowski K, Piekutowski K. Wolne rodniki tlenowe. Ochronne działanie witamin antyoksydacyjnych w prewen- cji i leczeniu nowotworów. Współczesna Onkologia 1999; 4: 143-144.

5. Doldo E, Costanza G, Agostinelli S, et al. Vitamin A, cancer treatment and prevention: the new role of cellular retinol binding proteins. Biomed Res Int. 2015; 2015: 624-627.

6. di Masi A, Leboffe L, De Marinis E, et al. Retinoic acid receptors: from molecular mechanisms to cancer therapy. Mol Aspects Med. 2015; 41: 1-115.

7. Koushik A, Wang M, Anderson KE, et al. Intake of vitamins $A, C$, and $E$ and folate and the risk of ovarian cancer in a pooled analysis of 10 cohort studies. Cancer Causes Control 2015; 26: 1315-1327.

8. Thomson CA, Neuhouser ML, Shikany JM, et al. The role of antioxidants and vitamin A in ovarian cancer: results from the Women's Health Initiative. Nutr Cancer. 2008; 6: 710- 719.

9. Mittal N, Malpani S, Dyson M et al. Fenretinide: a novel treatment for endometrial cancer. PLoS One 2014; 9: e110410.

10. Tanabe K, Utsunomiya H, Tamura M, et al. Expression of retinoic acid receptors in human endometrial carcinoma. Cancer Sci 2008; 99: 267-271.

11. Ju J, Picinich SC, Yang Z, et al. Cancer - preventive activities of tocopherols and tocotrienols. Carcinogenesis 2010; 4: 533-542.

12. Mahabir S, Schendel K, Dong YQ, et al. Dietary $\alpha-, \beta-, \gamma-$ and $\delta$-tocopherols in lung cancer risk. Int $\mathrm{J}$ Cancer 2008; 5: 1173-1180.

13. Sen CK, Khanna S, Roy S. Tocotrienol: the natural vitamin E to defend the nervous system? Ann. N. Y. Acad. Sci., 2004; 1031: 127-142.

14. Campbell SE, Stone WL, Whaley SG, Qui M, Krishnan K. Gamma (gamma) tocopherol upregulates peroxisome proliferator activated receptor (PPAR) gamma (gamma) expression in SW 480 human colon cancer cell lines. BMC Cancer, 2003; 3: 25.

15. Abate A, Yang G, Dennery PA, Oberle S, Schroder H. Synergistic inhibition of cyclooxygenase-2 expression by vitamin $\mathrm{E}$ and aspirin. Free Radic. Biol. Med., 2000; 29: 1135-1142.

16. Zingg JM, Azzi A. Non - antioxidant activities of vitamin E. Curr. Med. Chem., 2004; 11: 1113-1133.

17. Breyer I, Azzi A. Differential inhibition by alpha - and beta tocopherol of human erythroleukemia cell adhesion: role of integrins. Free Radic. Biol. Med., 2001; 30: 1381-1389.

18. Gysin R, Azzi A, Visarius T. Gamma - tocopherol inhibits human cancer cell cycle progression and cell proliferation by down - regulation of cyclins. FASEB J., 2002; 16: 1952-1954.

19. Thomson CA, Neuhouser ML, Shikany JM, et al. The role of antioxidants and vitamin A in ovarian cancer: results from the Women's Health Initiative. Nutr Cancer 2008; 60: 710-719.

20. Gifkins D, Olson SH, Paddock L, et al. Total and individual antioxidant intake and risk of epithelial ovarian cancer. BMC Cancer 2012; 12: 211-215.

21. Chang ET, Lee VS, Canchola AJ, et al. Diet and risk of ovarian cancer in the California Teachers Study cohort. Am J Epidemiol 2007; 165: 802-813.

22. Xu WH, Dai $Q$, Xiang YB, et al. Nutritional factors in relation to endometrial cancer: a report from a population - based case - control study in Shanghai, China. Int J Cancer 2007; 120: 1776-1781.

23. McCann SE, Freudenheim JL, Marshall JR, et al. Diet in the epidemiology of endometrial cancer in western New York (United States). Cancer Causes Control 2000; 11: 965-974.

24. Maćkowiak K, Torliński L. Współczesne poglądy na rolę witaminy C w fizjologii i patologii człowieka. Nowiny Lekarskie 2007; 4: 349-356. 
25. Plagens-Rotman K, Żak E, Pięta B. Odds ratio analysis in women with endometrial cancer. Prz. Menopauz. 2016; 1: 12-19.

26. Plagens-Rotman K, Piskorz-Szymendera M, Chmaj-Wierzchowska, Pięta B. Breast cancer - Analysis of the selected risk factors. Eur. J. Gynaecol. Oncol. 2017; 3: 425-430.

27. Zhang PY, Xu X, Li XC. Cardiovascular diseases: oxidative damage and antioxidant protection. Eur Rev Med Pharmacol Sci. 2014; 20: 3091-3096.

28. Piasek A, Bartoszek A, Namieśnik J. Substancje pochodzenia roślinnego przeciwdziałające kardiotoksyczności towarzyszącej chemioterapii nowotworów. Postępy Hig Med Dośw. 2009; 63: 142-158.

29. Szymańska-Pasternak J, Janicka A, Bober J. Witamina C jako oręż w walce z rakiem. Onkol Prakt Klin. 2014; 1: 9-23.

30. Janda K, Kasprzak M, Wolska J. Witamina C - budowa, właściwości, funkcje i występowanie. Pom J Life Sci 2015; 4: 419-425.

31. Tabatabaei-Malazy O, Nikfar S, Laridżani B, Abdollahi M. Influence of ascorbic acid supplementation on type 2 diabetes mellitus in observational and randomized controlled trials; a systematic review with meta - analysis. J Pharm Pharm Sci. 2014; 4: 554-582.

32. Ma Y, Chapman J, Levine Ml i wsp. High dose parenteral ascorbate enhanced chemosensitivity of ovarian cancer and reducedtoxicity of chemotherapy. Sci Transl Med. 2014; 222: 222ra18.

33. Kuiper C, Molenaar IG, Dachs GU et al. Low ascorbate levels are associated with increased hypoxia-inducible factor- 1 activity and an aggressive tumor phenotype in endometrial cancer. Cancer Res 2010; 70: 5749-5758.

34. Grant WB, Garland CF. The association of solar ultraviolet $B$ (UVB) with reducing risk of cancer: multifactorial ecologic analysis of geographic variation in age - adjusted cancer mortality rates. Anticancer Res 2006; 26: 2687-2699.

35. Robsahm TE, Tretli S, Dahlback A et al. Vitamin D3 from sunlight may improve the prognosis of breast - , colon- and prostatę cancer (Norway). Cancer Causes Control 2004; 15: 149-158.

36. Tagliabue E, Raimondi S, Gandini S. Vitamin D, cancer risk, and mortality. Adv Food Nutr Res 2015; 75: 1-52.

37. Meeker S, Seamons A, Maggio-Price L et al. Protective links between vitamin $D$, inflammatory bowel disease and colon cancer. World J Gastroenterol 2016; 22: 933-948.

38. La Marra F, Stinco G, Buligan C, Chiriacò G, et al. Immunohistochemical evaluation of vitamin $D$ receptor (VDR) expression in cutaneous melanoma tissues and four VDR gene polymorphisms. Cancer Biol Med. 2017; 2:162-175.

39. Beaudin SG, Robilotto S, Welsh J. Comparative regulation of gene expression by 1,25 - dihydroxyvitamin D3 in cells derived from normal mammary tissue and breast cancer. J Steroid Biochem Mol Biol. 2015; 148: 96-102.

40. Upadhyay SK, Verone A, Shoemaker S, Qin M, et al. 1,25 - Dihydroxyvitamin D3 (1,25(OH)2D3) Signaling Capacity and the Epithelial - Mesenchymal Transition in Non Small Cell Lung Cancer (NSCLC): Implications for Use of 1,25(OH)2D3 in NSCLC Treatment. Cancers (Basel). 2013; 8; 4:1504-1521.

41. Christakos S, Dhawan P, Verstuyf A, et al. Vitamin D: metabolism, molecular mechanism of action, and pleiotropic effects. Physiol Rev 2016; 96: 365-408.
42. Martinez-Miguel P, Valdivielso JM, Medrano-Andres D, et al. The active form of vitamin $D$, calcitriol, induces a complex dual upregulation of endothelin and nitric oxide in cultured endothelial cells. Am J Physiol Endocrinol Metab 2014; 307 : E1085-E1096.

43. Bakhru A, Mallinger JB, Buckanovich RJ, et al. Casting light on 25 - hydroxyvitamin $D$ deficiency in ovarian cancer: a study from the NHANES. Gynecol Oncol 2010; 119: 314-318.

44. Yin L, Grandi N, Raum E, et al. Meta - analysis: Circulating vitamin D and ovarian cancer risk. Gynecol Oncol. 2011; 121: 369-375.

45. Walentowicz-Sadlecka M, Grabiec M, Sadlecki P, et al. $25(\mathrm{OH}) \mathrm{D} 3$ in patients with ovarian cancer and its correlation with survival. Clin Biochem. 2012; 45: 1568-01572.

46. Kim YI. Will mandatory folic acid fortification prevent or promote cancer? Am J Clin Nutr 2004; 5: 1123-1128.

47. Powers HJ. Interaction among Folate, Riboflavin, Genotype, and Cancer, with Reference to Colorectal and Cervical Cancer. J Nutr 2005, 135: 2960S-2966S.

48. Oaks BM, Dodd KW, Meinhold CL, Jiao L, Church TR, Stolzenberg-Solomon RZ (2010) Folate intake, post-folic acid grain fortification, and pancreatic cancer risk in the prostate, lung, colorectal, and ovarian cancer screening trial. Am J Clin Nutr 91(2): 449-455.

49. Czyżewska-Majchrzak Ł, Paradowska P. Skutki niedoboru i ryzyko suplementacji folianów w diecie. Nowiny Lek 2010; 79(6): 457-463.

50. Larsson SC, Giovannucci E, Wolk A. Dietary folate intake and incidence of ovarian cancer: the Swedish Mammography Cohort. J Natl Cancer Inst. 2004; 3: 396-402.

51. Kotsopoulos J, Hecht JL, Marotti JD. Relationship between dietary and supplemental intake of folate, methionine, vitamin B6 and folate receptor $\alpha$ expression in ovarian tumors. Int J Cancer. 2010 May 1; 126(9): 2191-2198.

52. Du L, Wang $\mathrm{Y}$, Zhang $\mathrm{H}$ et al. Folate intake and the risk of endometrial cancer: A meta-analysis. Oncotarget. 2016; 7 : 85176-85184.

53. Zeng $\mathrm{H}$, Combs GF. Selenium as an anticancer nutrient: roles in cell proliferation and tumor cell invasion. J Nutr Biochem 2008; 1: 1-7.

54. Olejnik A, Tomczyk J, Kowalska K, Grajek W. Rola naturalnych składników diety w chemioprewencji nowotworów jelita grubego. Post Hig Med Dośw 2010, 64: 175-187.

55. Zabłocka K, Biernat J. Wpływ wybranych składników pożywienia na ryzyko rozwoju raka płuca - nienasycone kwasy tłuszczowe, izotiocyjaniany, selen. Współczesna Onkol 2010, 1: 54-58.

Artykuł przyjęty do redakcji: 05.04.2020.

Artykuł przyjęty do publikacji: 10.10.2020.

Źródło finansowania: praca nie jest finansowana z żadnego źródła. Konflikt interesów: Autorzy deklarują brak konfliktu interesów.

Adres do korespondencji:
Katarzyna Plagens-Rotman
ul. Ks. Kard. Stefana Wyszyńskiego 38
$62-200$ Gniezno
e-mail: plagens.rotman@gmail.com
Państwowa Wyższa Szkoła Zawodowa im. Hipolita Cegielskiego

